\title{
Measure of the resilience to Spanish economic crisis: the role of specialization
}

\author{
Ana Angulo* • Jesus Mur • Javier Trivez \\ University of Zaragoza, Spain
}

Received: 11 September 2014

Revised: 23 December 2014

Accepted: 23 December 2014

\begin{abstract}
Forecasting regional variables provides very important information for political, institutional and economic agents. In this paper, we use predictions from spatial panel data models to evaluate regional resilience to the present economic crisis in terms of annual growth rate of employment. Furthermore, we evaluate whether specialization plays a significant role in the degree of resilience to the economic crisis suffered in Spain from 2007. Results show that while specialization in energy and manufacturing, construction or finance and other activities in the tertiary sector decreases resilience to the crisis, specialization in distribution, transport and common services enlarges the availability of returning to his pre-shock growth path. Furthermore, those regions specialized in distribution, transport and common services and agriculture are even super-resilience to the crisis.
\end{abstract}

Keywords: forecasting regional data, resilience to the Spanish economic crisis, role of specialization, dynamic spatial panel data model

JEL Classification Codes: C21, C22, C23, C53, R15

\section{Introduction}

The field of panel data models has received considerable attention during the last decade. Panel data literature offers the opportunity of allowing for unobservable cross-sectional and time-period specific effects. Other advantages of panel data are that these models are generally more informative and contain more variation and less collinearity between variables. The use of panel data leads to more degrees of freedom and, hence, increases the efficiency of the estimation. Panel data also allow for the specification of more complicated behavioural hypotheses, including effects that cannot be addressed using pure cross-sectional or time-series data (Wooldridge, 2002; Arellano, 2003; Hsiao, 2003; Baltagi, 2005).

\footnotetext{
*Corresponding author. E-mail: aangulo@unizar.es.

Citation: Angulo, A., J. Mur and J. Trivez (2014) Measure of the resilience to Spanish economic crisis: the role of specialization, Economics and Business Letters, 3(4), 263-275.
} 
When cross-sectional data refers to spatial units (municipalities, provinces, regions or countries) the spatial dependence between cross-sectional units at each point in time is also important. Spatial dependence implies that, due to spillover effects (e.g., commuter labour or trade flows), neighbouring regions may have similar economic performance. Hence, we expect to improve traditional panel data models by paying attention to the location of the spatial units. There has been a growing interest in the estimation of panel data models with spatial dependence: see Kelejian and Prucha (2002), Elhorst (2003, 2010), Yang et al. (2006), Baltagi et al. (2006), Kapoor et al. (2007), Kelejian et al. (2006) or Pesaran (2006). Prediction with these type of models is analysed in Baltagi and Li $(2004,2006)$ for predicting per-capita cigarette and liquor consumption in the United States, in Longhi and Nijkamp (2007) for forecasting the regional labour market in West German regions, while Baltagi et al. (2012) make performance comparison of different spatial panel data models.

Since there is a consensus on the good performance of these model for forecasting, aim of this paper is to use forecasts from a spatial panel data model to evaluate the impact of the actual economic crisis on annual growth rate of employment in Spain, following Fingleton and Palombi (2013). The economic crisis started in Spain at the end of 2007, then we estimate and check several panel data models estimated for the period 1980-2006. Secondly, estimation results are used to forecast the annual growth rate of employment by Spanish provinces for the period 2007-2010. The predicted values for each region represent the counterfactual (or projected) annual growth rate of employment expected in absent of the economic crisis. That is, forecast values purged of the effect of crisis. Finally, we compare forecasts with actual values as a measure of the crisis effects on annual growth rate of employment. Three cases can be distinguished: i) a small difference (actual values similar to its counterfactual) suggests (long-run) regional resilience, since the region is able to return to his pre-shock growth path; ii) a positive difference would indicate super-resilience since the region is able to more than rebound; and iii) a negative difference (actual values below its counterfactual) suggests lack of resilience or region's failure to recover from the shock.

Since the economic crisis has not affected to all economic sectors equally, our conclusions will refer to the sectorial specialization of the regions distinguishing the following sectors: i) agriculture; ii) energy and manufacturing; iii) construction; iv) distribution, transport and common services; v) finance and other services; and vi) non-market services. We measure the degree of specialization through the localization quotient.

The structure of the present paper is as follows. In Section 2, we provide a description of the spatial panel data model we consider in our application. Section 3 is devoted to the presentation of the data. In Section 4, we present the main estimation results. Finally, the paper finishes with a section of concluding remarks.

\section{Methods}

Our base model is the pooled data model:

$$
\begin{aligned}
& y_{t}=x_{t} \beta+\varepsilon_{t} \quad t=1, \ldots, T \\
& y_{t}=\left[\begin{array}{c}
y_{1 t} \\
y_{2 t} \\
\vdots \\
y_{R t}
\end{array}\right] ; x_{t}=\left[\begin{array}{cccc}
1 & x_{1,1 t} & \vdots & x_{k, 1 t} \\
1 & x_{1,2 t} & \vdots & x_{k, 2 t} \\
\vdots & \vdots & \vdots & \vdots \\
1 & x_{1, R t} & \vdots & x_{k, R t}
\end{array}\right] ; \varepsilon_{t}=\left[\begin{array}{c}
\varepsilon_{1 t} \\
\varepsilon_{2 t} \\
\vdots \\
\varepsilon_{R t}
\end{array}\right]
\end{aligned}
$$


where $y_{t}$ is the annual growth rate of employment at time $\mathrm{t}$ in all regions $(\mathrm{r}=1, \ldots, \mathrm{R}) ; x_{t}$ represent the matrix of explanatory variables in period $t$, which includes the growth rate of gross value added and a set of dummy variables referred to whether or not region $r$ is specialised in an specific sector in period $\mathrm{t} ; \beta$ represent a $((\mathrm{k}+1) \mathrm{x} 1)$ vector of parameters to be estimated.

Next, the pooled model (1) is extended by the consideration of the vector $\mu=\left[\mu_{1}, \mu_{2}, \ldots, \mu_{R}\right]$ 'that captures the individual heterogeneity or, in other terms, controls for the effects of omitted variables, as follows:

$$
\mathrm{y}_{\mathrm{t}}=\mathrm{x}_{\mathrm{t}} \beta+\mu+\varepsilon_{\mathrm{t}} \quad \mu=\left[\begin{array}{c}
\mu_{1} \\
\mu_{2} \\
\vdots \\
\mu_{\mathrm{R}}
\end{array}\right] ; \quad \mathrm{t}=1,2, \ldots \mathrm{T}
$$

The individual heterogeneity $\mu$ can be treated as a vector of fixed parameters to be estimated or a random vector with a normal distribution, $\mu \sim \mathrm{N}\left[0, \sigma_{\mu}^{2} \mathrm{I}_{R}\right]$. In the first case, we obtain the so-called fixed effects model while the second is the random effects model. Finally, $\varepsilon_{\mathrm{t}}$ is a $(\mathrm{Rx} 1)$ vector of random terms.

Discussion about random or fixed effects models appears routinely in all panel estimations (Hsiao, 2003). The key issue in this choice concerns whether or not the omitted variables (represented with $\mu$ ) are correlated with the explanatory variables included in the model $\left(\mathrm{x}_{\mathrm{t}}\right)$. As it is well-known, if this is the case, the fixed effects models are consistent, since they provide a way of controlling for omitted variable bias, while the random effect estimators are inconsistent. Due to this fact, in our case, we propose the Fixed Effects (FE) model as the compelling specification since we assume that the omitted variables in our model are most likely correlated with the included ones. Furthermore, as Elhorst (2003) indicates, in the context of a spatial data set, the FE model is advisable because the spatial units of observation are neither representative of a larger population nor are potentially able to go to infinity in a regular fashion. Nevertheless, the Hausman (1978) test will also be applied to confirm our decision.

Next, model can be improved from the consideration of temporal effects (dynamic panel data model) and of spatial dependence (such as Spatial Lag X model, SLX, or the Spatial Lag model, SLM). A general model that includes both issues is the dynamic spatial Durbin model, which can be expressed as follows:

$$
\mathrm{y}_{\mathrm{t}}=\tau \mathrm{y}_{\mathrm{t}-1}+\rho \mathrm{Wy}_{\mathrm{t}}+\mathrm{x}_{\mathrm{t}} \beta+\mathrm{W} \mathrm{x}_{\mathrm{t}} \theta+\mu+\varepsilon_{\mathrm{t}}
$$

Where the weights matrix, $W$, is a square $\mathrm{R}$ by $\mathrm{R}$ matrix whose entries measure the strength of interregional interaction, and zeros on the main diagonal. Furthermore, model (3) nests the following dynamic spatial panel data models that can also fit our case:

- The dynamic Spatial Lag Model (SLM):

$$
\mathrm{y}_{\mathrm{t}}=\tau \mathrm{y}_{\mathrm{t}-1}+\rho \mathrm{Wy}_{\mathrm{t}}+\mathrm{x}_{\mathrm{t}} \beta+\mu+\varepsilon_{\mathrm{t}}
$$

- The dynamic Spatial Error Model (SEM):

$$
\begin{aligned}
& \mathrm{y}_{\mathrm{t}}=\tau \mathrm{y}_{\mathrm{t}-1}+\mathrm{x}_{\mathrm{t}} \beta+\mu+\mathrm{u}_{\mathrm{t}} \\
& \mathrm{u}_{\mathrm{t}}=\lambda \mathrm{W}_{\mathrm{u}_{\mathrm{t}}}+\varepsilon_{\mathrm{t}}
\end{aligned}
$$

The nesting structure among previous models is shown in Figure 1. 
Figure 1. The nesting structure among the proposed spatial panel data models

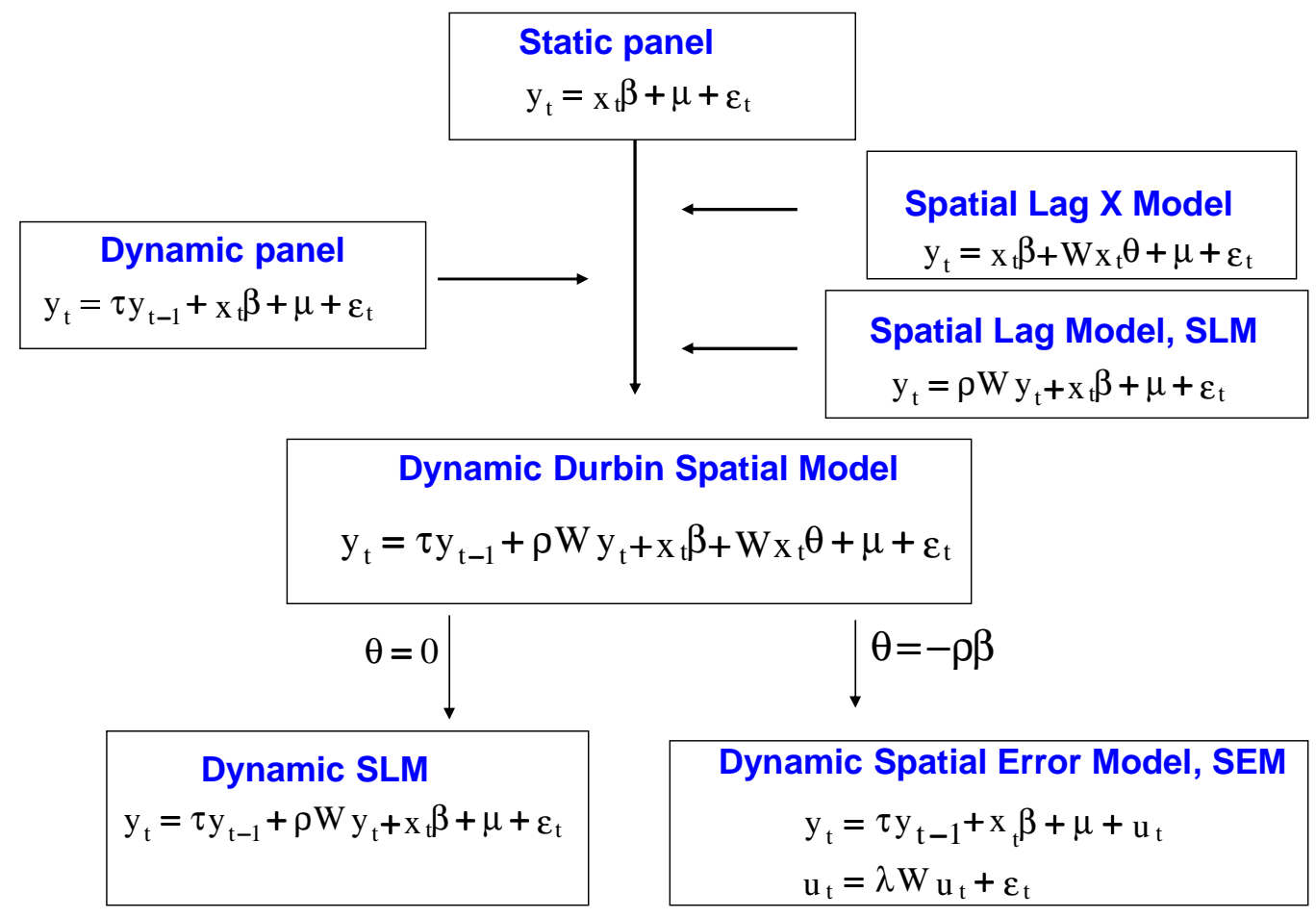

To cope with our objective, we proceed as follows:

i) First, we estimate all models for the period 1980-2006, and we select the specification that better fits our data.

ii) Secondly, estimation results are used to forecast the annual growth rate of employment by provinces for the period 2007-2010. The forecasts are considered as the counterfactual (or projected) annual growth rates of employment in absence of the economic crisis.

iii) Finally, we compare forecasted with the actual values as a measure of impact of the crisis.

\section{Data}

In the application that follows, we use data on total employment in 47 Spanish regions (NUTS III administrative spatial unit in terms of Eurostat). As said before, the annual growth rate of employment will be explained by the annual growth rate of gross value added. The model also includes six dummy variables, which capture the effect on employment growth rate of regional specialization in the following sectors: i) agriculture; ii) energy and manufacturing; iii) construction; iv) distribution, transport and common services; v) finance and other services; and vi) non-market services. The data for all the variables are gathered, for the period 1980 to 2010, from the Cambridge Database.

Firstly, we show the evolution of total employment along the sampling period (Figure 2). As observed in the graph, there is a clear decrease in employment around years 2007 and 2008, due to the economic crisis in Spain. 
Figure 2. Evolution of total employment in Spain

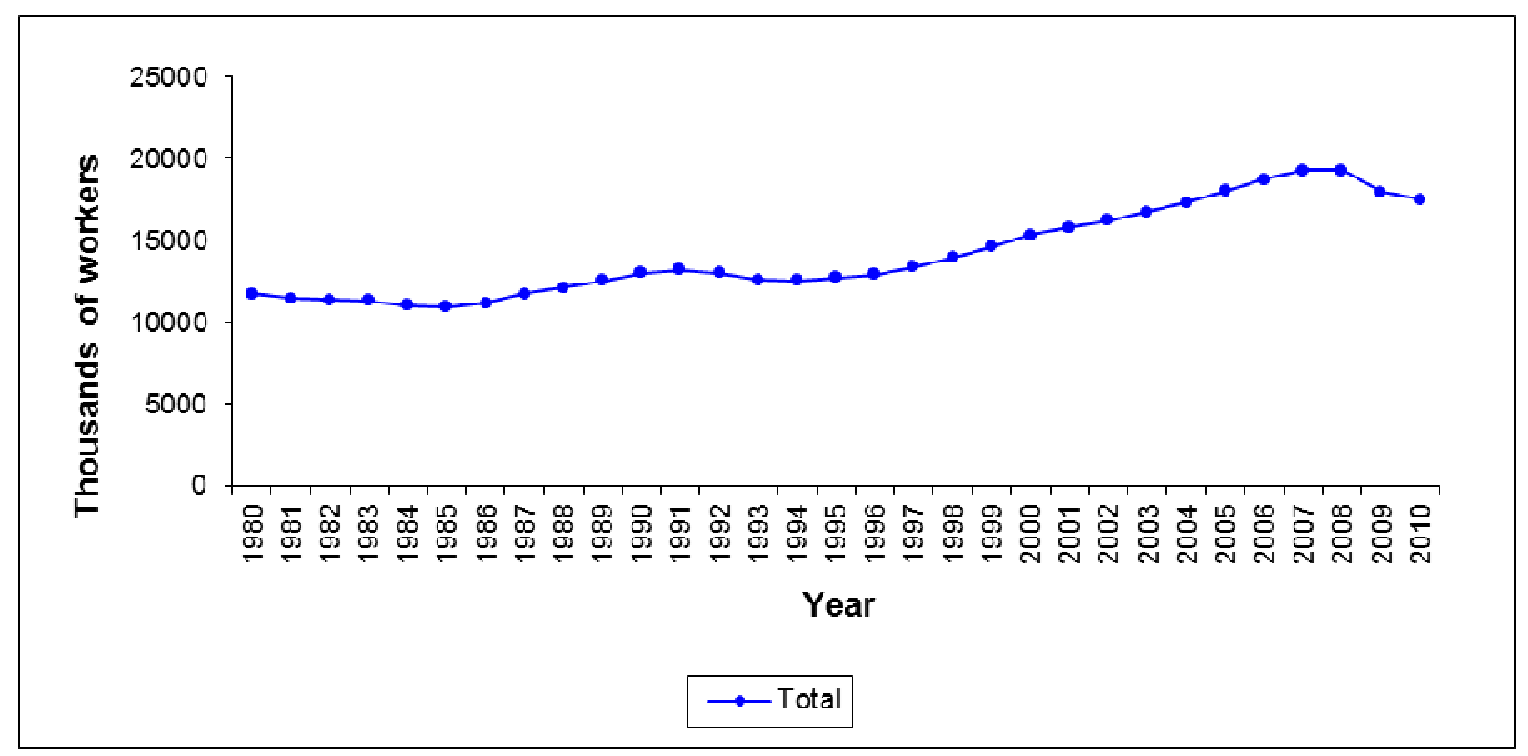

If we pay attention to the evolution of employment by the different economic activity sectors (Figure 3) we observe a similar pattern. However, important differences seem to exist among sectors. For instance, while in the agriculture sector the level of employment in the period previous to the crisis remains almost unaffected, a strong decrease takes place in the cases of construction or energy and manufacturing.

Figure 3. Evolution of employment in the different economic sectors in Spain

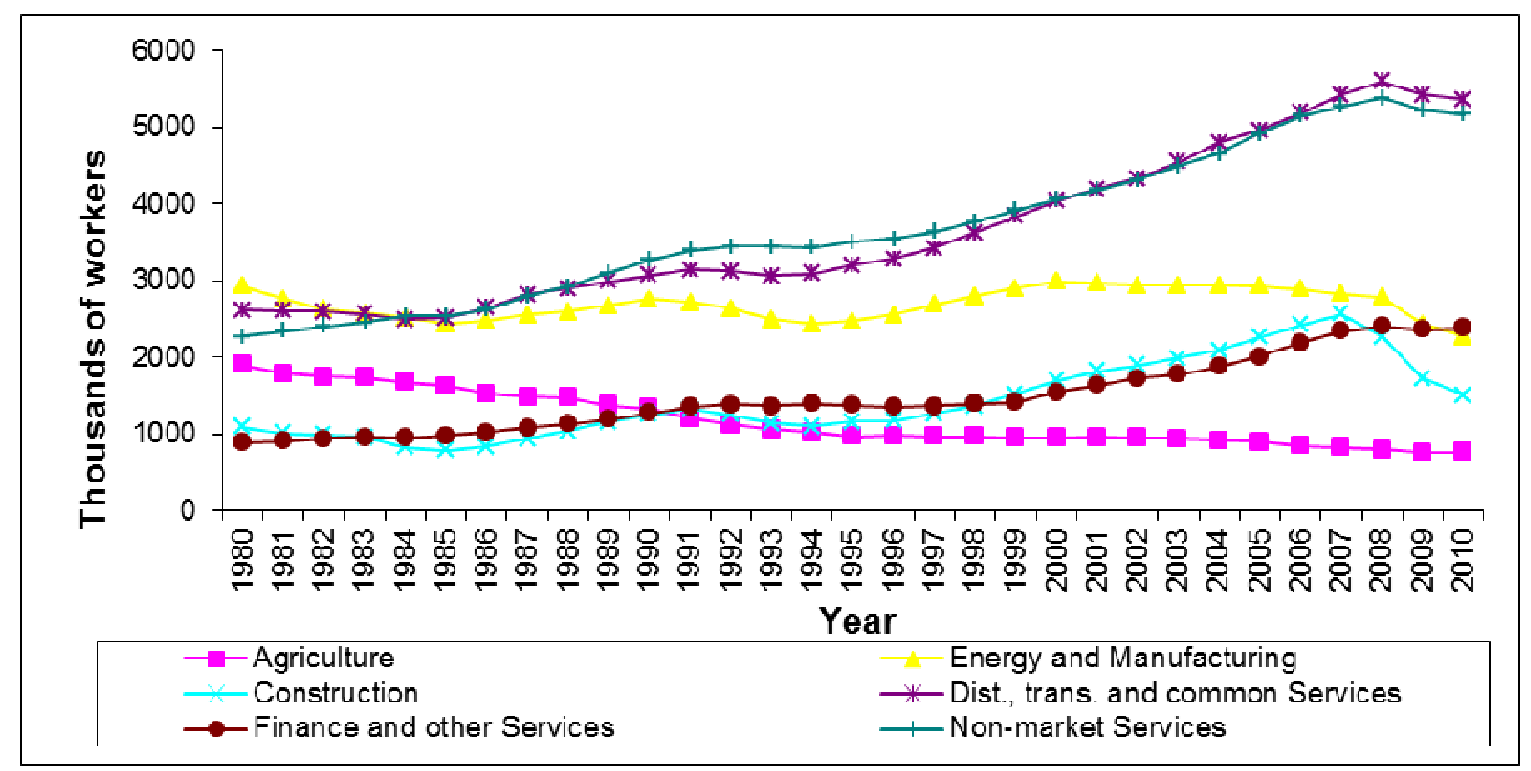

As indicated before, we want to analyse the role of specialization on employment growth rate. To cope with this objective, we calculate the localization quotient (originally introduced by Florence, 1939) for region $r$ and sector $i$ in period t, $Q L_{i r, t}$, as follows:

$$
Q L_{i r, t}=\frac{E_{i, t}^{r} / E_{\bullet^{r}, t}^{r}}{E_{i, t}^{\cdot} / E_{\mathbf{\bullet}_{, t}}^{\cdot}}
$$


where $E_{i, t}^{\bullet}$ measures the number of employees in sector $i$ in period $\mathrm{t} ; E_{\bullet, t}^{\bullet}$, the total number of employees in Spain (the 47 regions as a whole) in period t; $E_{i, t}^{r}$, the number of employees in sector $i$ and region $r$ in period t; and $E_{\bullet, t}^{r}$, the total number of employees in region $r$ in period t.

Figure 4. Location quotes by economic sectors in 2010. Specialized regions in the different economic sector in 2010

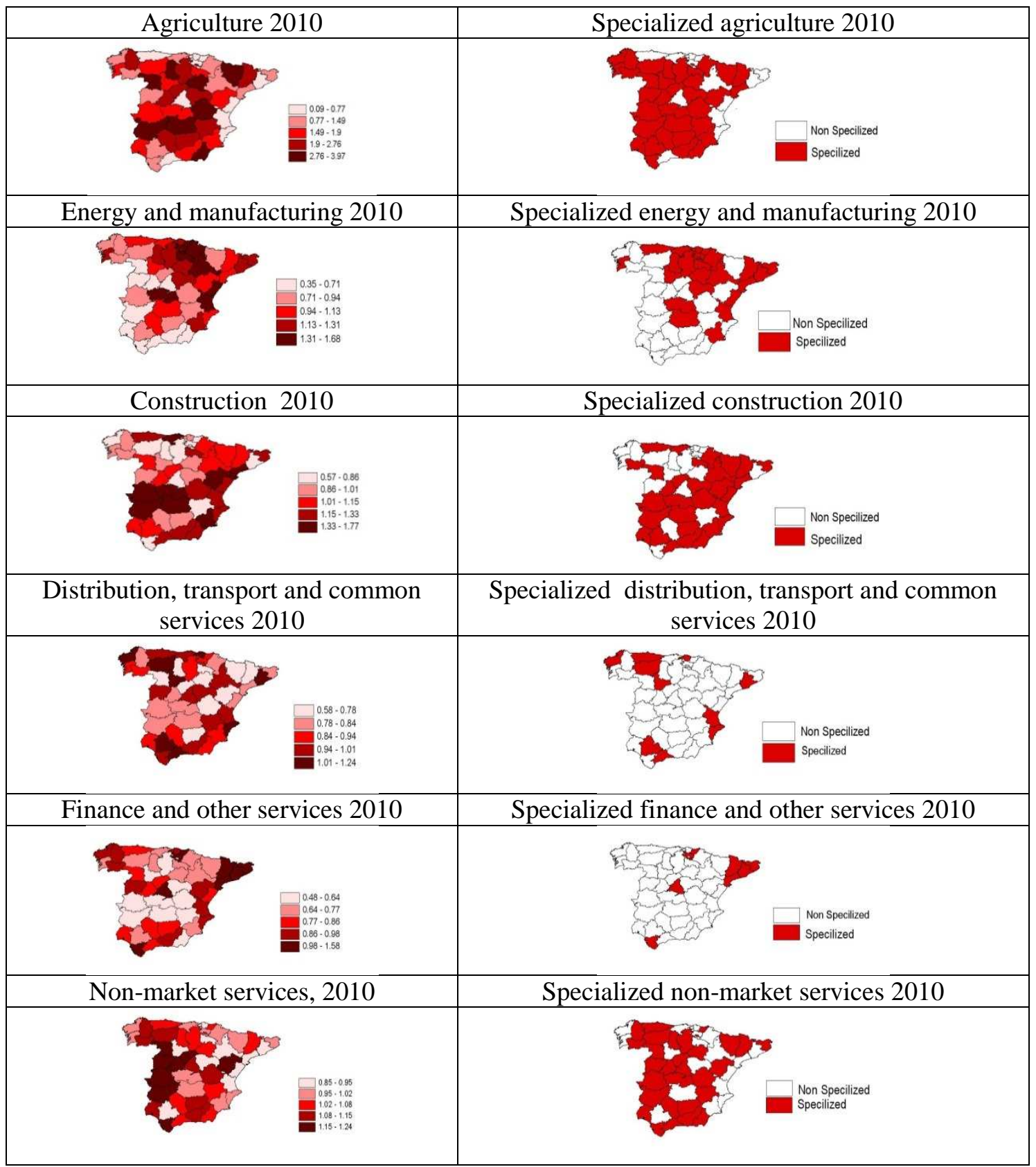


The localization quotient is a ratio that measures the regional share of workers in a specific sector relative to the national share of workers in that sector. If the localization quotient is larger than one, we conclude that the sector has a larger share of the employees in that region than the country as a whole, implying that this region is more specialized than average in the sector.

The localization quotients have been calculated for the period 1980-2010. From them, we have generated the corresponding dummy variables $D s p \_i$, that take a value of one if the corresponding region is specialized in sector $i$ (its localization quotient has a value greater than one), ( $i=$ agriculture; energy and manufacturing; construction; distribution, transport and common services; finance and other services; and non-market services). An example on the information generated is shown in Figure 4.

\section{Results}

We begin by estimating the pooled panel data model of equation (1). Results are shown in the first column of Table 1. Next, we estimate the Fixed Effects (FE) model (second column). The Hausman test confirms that this model outperforms the random effects model.

Next, we enlarge the model taking into account the spatial nature of the data through the estimation of the FE-SLX model (third column). In order to do that, first, we define the spatial weight matrix $(W)$ as the row-normalization of the four-nearest neighbor binary matrix ${ }^{1}$. However, specification tests do not give support to this model. Regarding, temporal autocorrelation, the Breusch-Godfrey test confirms that the null hypothesis of no temporal autocorrelation is rejected. Furthermore, the null of no spatial autocorrelation, in the form of SLM or SEM structures, is also rejected. Consequently, at this stage, we estimate the more general nesting model defined in equation (3), the dynamic Spatial Durbin Model (dynamic SDM), which nests the dynamic Spatial Lag Model (dynamic, SLM) and the dynamic Spatial Error Model (dynamic SEM). Results for the corresponding Likelihood Ratio (LR) tests indicate that the dynamic SLM specification is the preferred option for our data.

After the estimation of the dynamic SLM, we conclude that, in the pre-crisis period, there was a strong time persistence on the Spanish data on employment growth as well as significant spatial dependence among regions. As expected, the annual growth rate of the regional value added positively affects annual employment growth. Finally, regarding specialization, only specialization in agriculture, construction and non-market services have a positive (but not significant) effect on annual employment growth, while a specialization in distribution, transport and common services seems to be negative for annual employment growth in the pre-crisis period.

Next, estimation results (from period 1980-2006) are used to forecast the annual growth rate of employment by province for the period 2007-2010. However, as our main objective is to obtain the employment growth rate purged of the effect of crisis, we derive the future values of explicative variables as a seven-year moving average method in order to smooth the original data obtaining series that approximate the long term underlying trend(we follow Fingleton and Palombi, 2013). The predicted values for each region and time represent the counterfactual (or projected) employment growth rates in absence of the economic crisis.

\footnotetext{
${ }^{1}$ We choose the four-nearest neighbor specification for $\mathrm{W}$ due to the fact that employment flows are supposed to be more influenced by the distance between regions than by the contiguity or not among regions. However, our results are consistent with other $\mathrm{W}$ matrices.
} 
Table 1. Estimated parameters for alternative models and specification tests $(1980-2006)^{(a),(b)}$

\begin{tabular}{|c|c|c|c|c|c|}
\hline \multicolumn{6}{|c|}{ Dependent Variable: $\Delta \ln ($ total employment) } \\
\hline & $\begin{array}{l}\text { Pooled } \\
\text { (OLS) }\end{array}$ & $\begin{array}{c}\text { Fixed- } \\
\text { Effect } \\
\text { (FE) }\end{array}$ & FE-SLX & $\begin{array}{c}\text { Dynamic } \\
\text { Spatial } \\
\text { Durbin } \\
\text { Model }\end{array}$ & $\begin{array}{c}\text { Dynamic } \\
\text { Spatial } \\
\text { Lag } \\
\text { Model }\end{array}$ \\
\hline Constant & $\begin{array}{l}-0.003 \\
(-0.69)\end{array}$ & $\begin{array}{l}-0.002 \\
(-0.43)\end{array}$ & $\begin{array}{l}-0.006 \\
(-1.17)\end{array}$ & & \\
\hline$\Delta \ln (\text { total employment })_{\mathrm{t}-1}$ & & & & $\begin{array}{c}0.086^{*} \\
(3.34)\end{array}$ & $\begin{array}{c}0.088^{*} \\
(3.47)\end{array}$ \\
\hline$\Delta \operatorname{Ln}(\text { gross value added })_{\mathrm{t}}$ & $\begin{array}{l}0.553 * \\
(18.62)\end{array}$ & $\begin{array}{l}0.527 * \\
(17.51)\end{array}$ & $\begin{array}{l}0.457 * \\
(14.41)\end{array}$ & $\begin{array}{l}0.435 * \\
(14.20)\end{array}$ & $\begin{array}{l}0.444 * \\
(15.01)\end{array}$ \\
\hline $\mathrm{W} \Delta \mathrm{Ln}(\text { gross value added })_{\mathrm{t}}$ & & & $\begin{array}{c}0.294^{*} \\
(6.14)\end{array}$ & $\begin{array}{l}0.044 \\
(0.83)\end{array}$ & \\
\hline Dsp_agriculture $_{t}$ & $\begin{array}{c}-0.007 * \\
(-2.52)\end{array}$ & $\begin{array}{l}0.003 \\
(0.50)\end{array}$ & $\begin{array}{l}0.001 \\
(0.17)\end{array}$ & $\begin{array}{l}0.146 \\
(0.28)\end{array}$ & $\begin{array}{l}0.167 \\
(0.32)\end{array}$ \\
\hline Dsp_Energy and Manufact.t $_{\text {. }}$ & $\begin{array}{c}0.006^{*} \\
(2.42)\end{array}$ & $\begin{array}{l}0.001 \\
(0.12)\end{array}$ & $\begin{array}{l}-0.001 \\
(-0.13)\end{array}$ & $\begin{array}{l}-0.479 \\
(-1.13)\end{array}$ & $\begin{array}{l}-0.483 \\
(-1.14)\end{array}$ \\
\hline Dsp_Construction $_{t}$ & $\begin{array}{c}0.006^{*} \\
(3.12)\end{array}$ & $\begin{array}{c}0.006^{*} \\
(2.58)\end{array}$ & $\begin{array}{c}0.006^{*} \\
(2.61)\end{array}$ & $\begin{array}{l}0.361 \\
(1.59)\end{array}$ & $\begin{array}{l}0.353 \\
(1.55)\end{array}$ \\
\hline Dsp_ Dist., trans, c. services $_{t}$ & $\begin{array}{c}-0.005^{*} \\
(-2.13)\end{array}$ & $\begin{array}{c}-0.012 * \\
(-3.81)\end{array}$ & $\begin{array}{c}-0.012 * \\
(-3.90)\end{array}$ & $\begin{array}{c}-1.026^{*} \\
(-3.37)\end{array}$ & $\begin{array}{c}-1.013 * \\
(-3.34)\end{array}$ \\
\hline 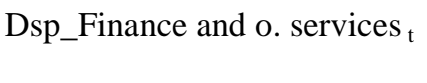 & $\begin{array}{l}-0.002 \\
(-0.54)\end{array}$ & $\begin{array}{c}-0.017 * \\
(-2.96)\end{array}$ & $\begin{array}{c}-0.015^{*} \\
(-2.58)\end{array}$ & $\begin{array}{l}-1.068 \\
(-1.90)\end{array}$ & $\begin{array}{l}-1.069 \\
(-1.90)\end{array}$ \\
\hline Dsp_Non-market services ${ }_{t}$ & $\begin{array}{l}0.008 \\
(3.72)\end{array}$ & $\begin{array}{c}0.009 * \\
(3.13)\end{array}$ & $\begin{array}{c}0.007 * \\
(2.65)\end{array}$ & $\begin{array}{l}0.481 \\
(1.83)\end{array}$ & $\begin{array}{l}0.487 \\
(1.86)\end{array}$ \\
\hline$\hat{\rho}$ & & & & $\begin{array}{c}0.256^{*} \\
(7.61)\end{array}$ & $\begin{array}{c}0.267^{*} \\
(8.76)\end{array}$ \\
\hline
\end{tabular}

Hausman Test

$\mathrm{H}_{0}$ : Random Effect (RE)

$\mathrm{H}_{1}$ : Fixed Effect (FE)

Breusch-Godfrey Test:

$\mathrm{H}_{0}$ : No autocorrelation

$\mathrm{H}_{1}$ : Autocorrelation

\section{Testing for panel specification}

$$
39.01 *
$$

\section{Testing for temporal autocorrelation}

$26.86^{*}$

\begin{tabular}{|c|c|}
\hline \multicolumn{2}{|c|}{ Testing for spatial panel autocorrelation } \\
\hline LM test no spatial lag & $87.01 *$ \\
\hline Robust LM test no spatial lag & $22.70 *$ \\
\hline LM test no spatial error & $71.08 *$ \\
\hline Robust LM test no spatial error & $6.77 *$ \\
\hline \multicolumn{2}{|c|}{$\begin{array}{ll}\text { Testing for spatial and time panel specification } \\
\end{array}$} \\
\hline $\begin{array}{l}\text { LR test, Dynamic (D.) SDM vs. Static SDM } \\
\mathrm{H}_{0} \text { : Static SDM; } \mathrm{H}_{1} \text { : D. SDM }\end{array}$ & $11.18 *$ \\
\hline $\begin{array}{l}\text { LR test, Dynamic (D.) SDM vs. D. SEM } \\
\mathrm{H}_{0}: \text { D. SEM; } \mathrm{H}_{1}: \text { D. SDM }\end{array}$ & $11.21 *$ \\
\hline $\begin{array}{l}\text { LR test, D. SDM vs. D. SLM } \\
\mathrm{H}_{0}: \text { D. SLM; } \mathrm{H}_{1}: \text { D. SDM }\end{array}$ & 0.70 \\
\hline
\end{tabular}

(a) T-ratios in parenthesis. (b) An* means significance at the 5\% level.

Finally, forecast error (f.e.) for each region and time period is obtained as the difference between the actual employment growth and the forecasted values. This measure resumes the effect of the economic crisis. Table 2 shows the mean of the forecast errors for the post-crisis period (2007-2010) of all the regions which, as expected, is negative (-0.059). T-statistic tests are carried out to classify Spain as a whole as one of the three categories: i) not affected by the crisis, if we cannot reject the null $\mathrm{H}_{0}$ : $\mathrm{E}[\mathrm{f}$.e. $]=0$ against the alternative $\mathrm{H}_{1}$ : $\mathrm{E}[\mathrm{f} . \mathrm{e}] \neq$.0 ; ii) super-resilience, if we reject the null $\mathrm{H}_{0}$ : $E[f . e]=$.0 against the alternative $\mathrm{H}_{1}$ : $E[$ f.e. $]>0$; or iii) 
lack of resilience, if we reject the null $\mathrm{H}_{0}$ : $\mathrm{E}[\mathrm{f}$.e. $]=0$ against the alternative $\mathrm{H}_{1}$ : $\mathrm{E}[\mathrm{f} . \mathrm{e}]<0$. Results gathered in Table 2 shows that, on average, there is a lack of resilience or failure to recover from the shock.

Table 2. Testing on forecast error (f.e.) from the dynamic FE-SLM model in post-estimation sample (post-crisis: 2007-2009) for ALL the regions

\begin{tabular}{|c|c|c|c|c|c|}
\hline $\begin{array}{l}\text { Mean } \\
\text { forecast } \\
\text { error }\end{array}$ & $\begin{array}{l}\text { T-statistic: } \\
\mathrm{H}_{0}: \mathrm{E}[\text { f.e. }]=0\end{array}$ & $\begin{array}{c}\left.\mathrm{H}_{0} \text { : E[f.e. }\right]=0 \\
\mathrm{H}_{1} \text { : E[f.e. } \neq\end{array}$ & $\begin{array}{l}\mathrm{H}_{0}: \mathrm{E}[\text { f.e. }]=0 \\
\mathrm{H}_{1}: \mathrm{E}[\text { f.e. }]>0\end{array}$ & $\begin{aligned} \mathrm{H}_{0}: \mathrm{E}[\text { f.e. }] & =0 \\
\mathrm{H}_{1} \text { : } \mathrm{E}[\text { f.e. }] & <0\end{aligned}$ & Conclusion \\
\hline-0.059 & -5.851 & $R E J E C T(R)$ & $\begin{array}{c}\text { NOT REJECT } \\
\text { (NR) }\end{array}$ & REJECT $(R)$ & $\begin{array}{l}\text { Lack of Resilience } \\
\text { (Lack of R.) }\end{array}$ \\
\hline
\end{tabular}

Finally, the role of specialization on resilience to the crisis is analysed by disaggregating these forecasts by regional specialization categories. Results referred to specialized regions are gathered in Table 3. Data in the main diagonal (for instance, elements on cell $(i, i)$ ) refer to those regions specialized in only one sector (that indicated in row/column $i$ ). Data outside main diagonal (for instance, elements on cell $(i, j))$ refer to regions specialized in two sectors (those indicated in row $i$ and column $j$ ). Within cells, the four items refer to the following issues: the first refers to the mean forecast error of the corresponding provinces; the second refers to the t-test to test that the expected value of forecast error is equal to zero; the third results refers to the conclusion on Rejection (R) or Not Rejection (NR) of the null against three alternatives $\neq 0 />0 /<0$; the fourth item refers to the classification of this group of provinces.

As shown in Table 3, most of the cells reflect the same conclusion as that for the case of Spain: lack of resilience to the economic crisis. The worst situation corresponds to those regions specialized in construction, finance and other services or energy and manufacturing. Table 3 shows that there are three important exceptions: one refers to the super-resilience of the regions specialized in agriculture and in distribution, transport and common services, since they have improved their annual employment growth more than expected, in spite of the economic crisis. The two other exceptions refer to the small impact of the crisis for two groups of provinces: i) provinces specialized only in distribution, transport and common services; and ii) provinces specialized both in distribution, transport and common services and in non-market services.

Finally, similar information has been obtained for the case of provinces not specialized in any sectors. Results appear in Table 4.

As shown in Table 4, all the non-specialized provinces suffer from a lack of resilience. Whether the impact on specialized and non-specialized regions is significantly different can be analysed through the corresponding t-tests, whose results are displayed in Table 5.

As shown in Table 5, the level of resilience to the economic crisis is significantly higher for specialized provinces in the following sectors: i) agriculture; ii) agriculture and distribution, transport and common services; iii) agriculture and non-market services; and iv) distribution, transport and common services and non-market services. On the contrary, level of resilience is significantly lower for the provinces specialized in the following sectors: i) energy and manufacturing; ii) construction; iii) finance and other services; iv) energy and manufacturing and construction; v) energy and manufacturing and finances and other services; vi) construction and finance and other services; and vii) finance and non-market services. 
Table 3. Testing on forecast error (f.e.) from the dynamic FE-SLM model in post-estimation sample (post-crisis: 2007-2009) for SPECIALISED regions ${ }^{\text {(a) }}$

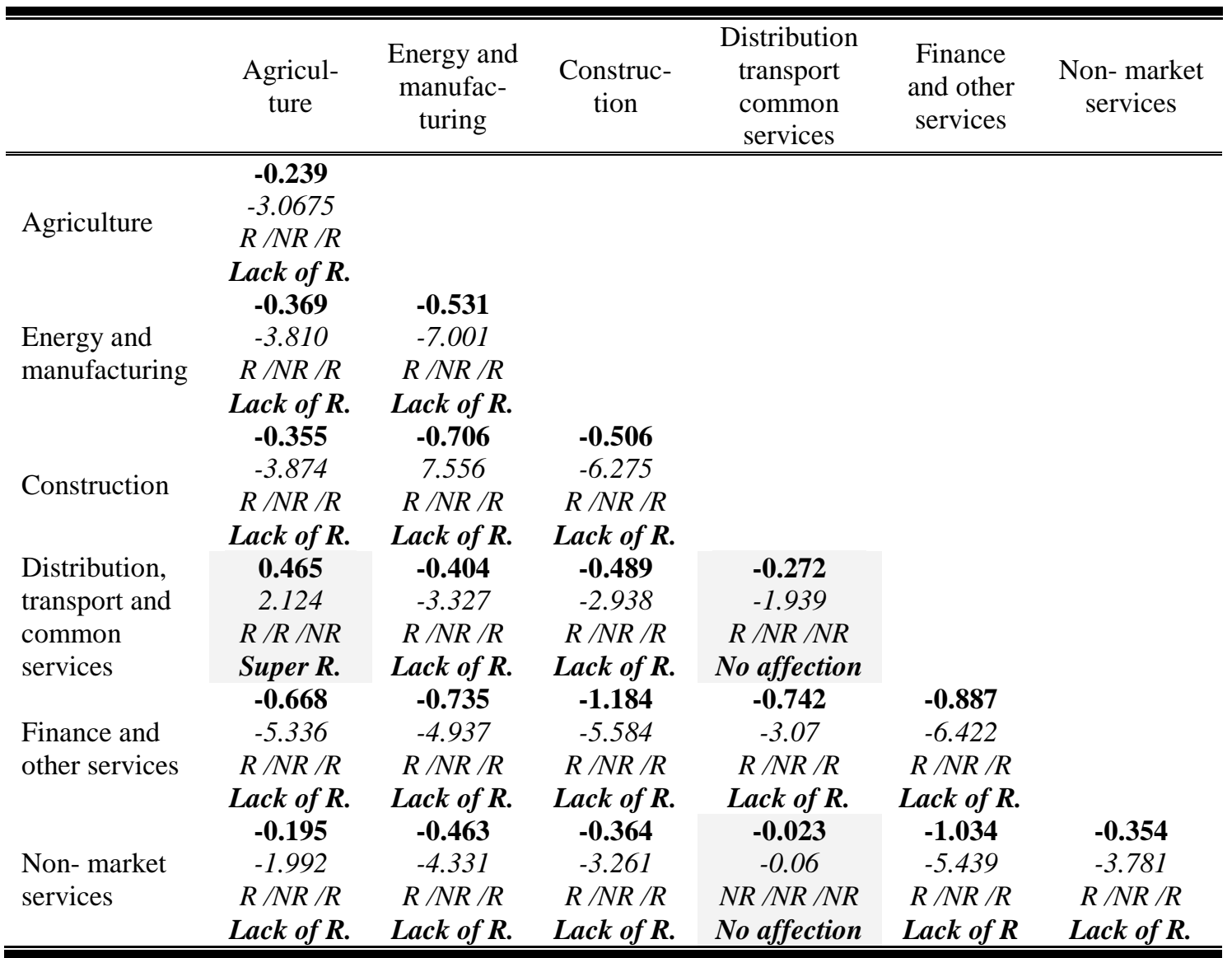

(a) Within cells, the four items refer to the following: the first refers to the mean forecast error of the corresponding regions; the second refers to the t-test to test that the expected value of forecast error is equal to zero; the third results refers to the conclusion on Rejection (R) or Not Rejection (NR) of the null against three alternatives $\neq 0 />0 /<0$; the fourth item refers to the classification of this group of regions. 
Table 4. Testing on forecast error (f.e.) from the dynamic FE-SLM model in post-estimation sample (post-crisis: 2007-2009) for NON-SPECIALISED regions ${ }^{\text {(a) }}$

\begin{tabular}{|c|c|c|c|c|c|c|}
\hline & $\begin{array}{l}\text { Agricul- } \\
\text { ture }\end{array}$ & $\begin{array}{l}\text { Energy and } \\
\text { manufac- } \\
\text { turing }\end{array}$ & $\begin{array}{l}\text { Construc- } \\
\text { tion }\end{array}$ & $\begin{array}{c}\text { Distribution } \\
\text { transport } \\
\text { common } \\
\text { services } \\
\end{array}$ & $\begin{array}{l}\text { Finance } \\
\text { and other } \\
\text { services }\end{array}$ & $\begin{array}{c}\text { Non- market } \\
\text { services }\end{array}$ \\
\hline Agriculture & $\begin{array}{c}\mathbf{- 0 . 9 3 7} \\
-9.319 \\
R / N R / R \\
\text { Lack of } \boldsymbol{R} .\end{array}$ & & & & & \\
\hline $\begin{array}{l}\text { Energy and } \\
\text { manufacturing }\end{array}$ & $\begin{array}{c}\mathbf{- 0 . 4 4 4} \\
-5.077 \\
R / N R / R \\
\text { Lack of } \boldsymbol{R} .\end{array}$ & $\begin{array}{c}\mathbf{- 0 . 3 0 0} \\
-2.685 \\
R / N R / R \\
\text { Lack of } \boldsymbol{R} .\end{array}$ & & & & \\
\hline Construction & $\begin{array}{c}\mathbf{- 0 . 4 9 2} \\
-5.00 \\
R / N R / R \\
\text { Lack of } \boldsymbol{R} .\end{array}$ & $\begin{array}{c}\mathbf{- 0 . 2 9 3} \\
-3.440 \\
R / N R / R \\
\text { Lack of } \boldsymbol{R} .\end{array}$ & $\begin{array}{c}-\mathbf{- 0 . 2 4 3} \\
-2.065 \\
R / N R / R \\
\text { Lack of } \boldsymbol{R} .\end{array}$ & & & \\
\hline $\begin{array}{l}\text { Distribution, } \\
\text { transport and } \\
\text { common } \\
\text { services }\end{array}$ & $\begin{array}{c}\mathbf{- 0 . 5 0 8} \\
-7.578 \\
R / N R / R \\
\text { Lack of } \boldsymbol{R} . \\
\mathbf{- 0 . 4 0 6}\end{array}$ & $\begin{array}{c}\mathbf{- 0 . 4 2 2} \\
-5.667 \\
R / N R / R \\
\text { Lack of } \boldsymbol{R} . \\
\mathbf{- 0 . 3 8 1}\end{array}$ & $\begin{array}{c}-\mathbf{0 . 4 0 9} \\
-5.617 \\
R / N R / R \\
\text { Lack of } \boldsymbol{R} . \\
\mathbf{- 0 . 3 7 7}\end{array}$ & $\begin{array}{c}\mathbf{- 0 . 4 6 4} \\
-6.088 \\
R / N R / R \\
\text { Lack of } \boldsymbol{R} \text {. } \\
\mathbf{- 0 . 4 0 9}\end{array}$ & -0.342 & \\
\hline $\begin{array}{l}\text { Finance and } \\
\text { other services }\end{array}$ & $\begin{array}{c}-5.777 \\
R / N R / R\end{array}$ & $\begin{array}{c}-5.243 \\
R / N R / R\end{array}$ & $\begin{array}{c}-5.511 \\
R / N R / R\end{array}$ & $\begin{array}{c}-5.961 \\
R / N R / R\end{array}$ & $\begin{array}{c}-4.683 \\
R / N R / R\end{array}$ & \\
\hline $\begin{array}{l}\text { Non- market } \\
\text { services }\end{array}$ & $\begin{array}{c}\text { Lack of } \boldsymbol{R} . \\
\quad \mathbf{- 0 . 6 4 2} \\
-7.479 \\
R / N R / R \\
\text { Lack of } \boldsymbol{R} .\end{array}$ & $\begin{array}{c}\text { Lack of } \boldsymbol{R} . \\
-\mathbf{- 0 . 4 1 1} \\
-5.264 \\
R / N R / R \\
\text { Lack of } \boldsymbol{R} .\end{array}$ & $\begin{array}{c}\text { Lack of } \boldsymbol{R} . \\
\quad \mathbf{- 0 . 4 6 0} \\
-5.549 \\
R / N R / R \\
\text { Lack of } \boldsymbol{R} .\end{array}$ & $\begin{array}{c}\text { Lack of } \boldsymbol{R} . \\
\mathbf{- 0 . 4 5 1} \\
-6.816 \\
R / N R / R \\
\text { Lack of } \boldsymbol{R} .\end{array}$ & $\begin{array}{c}\text { Lack of } \boldsymbol{R} . \\
\mathbf{- 0 . 3 6 7} \\
-5.274 \\
R / N R / R \\
\text { Lack of } \boldsymbol{R} \\
\end{array}$ & $\begin{array}{c}-\mathbf{0 . 5 1 8} \\
-5.681 \\
R / N R / R \\
\text { Lack of } \boldsymbol{R} .\end{array}$ \\
\hline
\end{tabular}

(a) Within cells, the four items refer to the following: the first refers to the mean forecast error of the corresponding regions; the second refers to the t-test to test that the expected value of forecast error is equal to zero; the third results refers to the conclusion on Rejection (R) or Not Rejection (NR) of the null against three alternatives $\neq 0 />0 /<0$; the fourth item refers to the classification of this group of regions.

Table 5. T-test to test significant differences on resilience to economic crisis between SPECIALISED and NONSPECIALISED regions ${ }^{(a)}$

\begin{tabular}{|c|c|c|c|c|c|c|}
\hline & $\begin{array}{l}\text { Agricul- } \\
\text { ture }\end{array}$ & $\begin{array}{l}\text { Energy } \\
\text { and } \\
\text { manufac- } \\
\text { turing }\end{array}$ & $\begin{array}{l}\text { Construc- } \\
\text { tion }\end{array}$ & $\begin{array}{l}\text { Distribu- } \\
\text { tion } \\
\text { transport } \\
\text { common } \\
\text { services }\end{array}$ & $\begin{array}{l}\text { Finance } \\
\text { and other } \\
\text { services }\end{array}$ & $\begin{array}{c}\text { Non- } \\
\text { market } \\
\text { services }\end{array}$ \\
\hline Agriculture & $4.833^{*}$ & & & & & \\
\hline \multirow{2}{*}{$\begin{array}{l}\text { Energy and } \\
\text { manufacturing } \\
\text { Construction }\end{array}$} & 0.520 & $-1.732 *$ & & & & \\
\hline & 1.023 & $-2.898 *$ & $-1.855^{*}$ & & & \\
\hline \multirow{3}{*}{$\begin{array}{l}\text { Distribution, transport } \\
\text { and common services } \\
\text { Finance and other } \\
\text { services } \\
\text { Non- market services }\end{array}$} & $4.346^{*}$ & 0.090 & -0.396 & 1.199 & & \\
\hline & -0.875 & $-1.669 *$ & $-2.739 *$ & -0.869 & $-2.899 *$ & \\
\hline & $3.426^{*}$ & -0.291 & 0.704 & $1.685^{*}$ & $-2.736 *$ & 1.207 \\
\hline
\end{tabular}

(a) An* means that differences are significantly higher (if positive) or lower (if negative) at 5\% level of significance. 


\section{Concluding remarks and references}

The econometric literature stresses the good performance of panel data models, in general, and spatial panel data models, in particular, for capturing unobservable heterogeneity present in the data. The results can be used for analyzing or predicting an economic variable. In this paper, we show the potential use of these models as a measure of the effect of the Spanish economic crisis on employment growth rate. We focus on the role of specialization on the economic resilience to the crisis. A dynamic FE-SLM spatial panel model is selected as the best specification for explaining the annual growth of employment rate in Spain for the period 1980-2006. Forecasts are generated for the period 2007-2010, representing the counterfactual (or projected) employment growth rates in absence of the economic crisis. Finally, we compare actual with forecast values as a measure of the effects of the crisis.

Our main results are the following. First, as expected, the economic crisis caused a significant decrease in annual employment growth rates in mostly all sectors. However, specialization makes a difference in the regional resilience: i) specialization in energy and manufacturing, construction or finance and other services decreases resilience to the crisis; ii) the specialization in distribution, transport and common services increases the chances of returning to the pre-shock growth path; and finally, iii) the specialization in distribution, transport and common services and agriculture makes regions super-resilience to the crisis.

Acknowledgements. The authors want to acknowledge the financial support received from ECO201236032-C03-01 project of Ministry of Economy and Competitiveness of the Government of Spain and the Department of Industry and Innovation of the Government of Aragon and the EUROPEAN SOCIAL FUND through the project GAEC group, Ref. S60.

\section{References}

Arellano, M. (2003) Panel data econometrics, Oxford University Press: Oxford.

Baltagi, B.H. (2005) Econometric analysis of panel data, third edition, Wiley: Chichester.

Baltagi, B.H. and Li, D. (2004) Prediction in the panel data model with spatial correlation, in Anselin, L., Florax, R.J.G.M. and Rey, S. (eds.) Advanced in spatial econometrics: methodology, tools and application, Springer-Verlag, Heidelberg (Germany), 283-295.

Baltagi, B.H. and Li, D. (2006) Prediction in the panel data model with spatial correlation: the case of liquor, Spatial Economic Analysis, 1(2), 175-185.

Baltagi, B.H., Song, S.H., Jung, B.C. and Koh, W. (2007) Testing for serial correlation, spatial autocorrelation and random effects using panel data, Journal of Econometrics, 140(1), 5-51.

Baltagi, B.H., Bresson, G. and Pirotte, A. (2012) Forecasting with spatial panel data, Computational Statistics and Data Analysis, 56(11), 3381-3397.

Elhorst, J.P. (2003) Specification and estimation of spatial panel data models, International Regional Science Review, 26(3), 244-268.

Elhorst, J.P. (2010) Spatial panel data models, in Fischer, M.M. and Getis, A. (eds.) Handbook of applied spatial analysis, Springer-Verlag: Berlin, 337-405.

Fingleton, B. and Palombi S. (2013) Spatial panel data estimation, counterfactual predictions and local economic resilience among British towns in the Victorian era, Regional Science and Urban Economics, 43(4), 649-660.

Florence, P. (1939) Report of the location of industry, Political and Economic Planning: London, UK.

Hausman, J.A. (1978) Specification tests in Econometrics, Econometrica, 46(6), 1251-1272.

Hsiao, C. (2003) Analysis of panel data, $2^{\text {nd }}$ edition, Cambridge University Press: Cambridge. 
Kapoor, M., Kelejian, H.H. and Prucha, I.R. (2007) Panel data models with spatially correlated error components, Journal of Econometrics, 140(1), 97-130.

Kelejian, H.H. and Prucha, I.R. (2002) 2SLS and OLS in a spatial autoregressive model with equal spatial weights, Regional Science and Urban Economics, 32(6), 691-707.

Kelejian, H.H., Prucha, I.R. and Yuzefovich, Y. (2006) Estimation problems in models with spatial weighting matrices which have blocks of equal elements, Journal of Regional Science, 46(3), 507-515.

Longhi, S. and Nijkamp, P. (2007) Forecasting regional labor market developments under spatial correlation, International Regional Science Review, 30(2), 100-119.

Pesaran, M.H. (2006) Estimation and inference in large heterogeneous panels with a multifactor error structure, Econometrica, 74(4), 967-1012.

Wooldridge, J. (2002) Econometric analysis of cross section and panel data, The MIT Press: Cambridge.

Yang, Z., Li, C. and Tse, Y.K. (2006) Functional form and spatial dependence in panels, Economics Letters, 91(1), 138-145. 